\title{
IMPLEMENTASI ALGORITMA BOYER MOORE PADA PENGEMBANGAN FIRST PERSON SHOOTER GAME TEBAK KATA
}

\author{
Andrian Prayoga, Agung Panji Sasmito, Deddy Rudhistiar \\ Program Studi Teknik Informatika S1, Fakultas Teknologi Industri \\ Institut Teknologi Nasional Malang, Jalan Raya Karanglo km 2 Malang, Indonesia \\ andrianprayoga46@gmail.com
}

\begin{abstract}
ABSTRAK
Tebak kata merupakan permainan yang menuntut pemain guna menduga kata yang tersembunyi satu demi satu per karakternya. Sampai disaat ini, pertumbuhan game tebak telah jadi banyak varian serupa pencarian kata, teka teki silang, permainan ejaan, serta anagram. Dalam perihal ini buat memberikan sesuatu tantangan baru, pada riset ini hendak melakukan pengembangan First Person Shooter pada permainan tebak kata. Pada pengembangan ini memakai algoritma pencarian string yang dikembangkan oleh Robert S. Boyer serta J. Strother Moore pada tahun 1977 yaitu algoritma Boyer- Moore. Studi yang dicoba yakni memandang berhasilnya Algoritma Boyer Moore dalam menerapkan pencocokkan kata. Berdasarkan hasil pengembangan First Person Shooter pada game Tebak Kata. Melakukan pencarian pattern satu kata pada teks yang berisikan lebih dari satu kata kunci jawaban yang dicara pada game. Tersimpulkan bahwa algoritma Boyer Moore berhasil melakukan pencarian string sebagai kecerdasan buatan pada game.
\end{abstract}

Kata Kunci: Tebak kata, Boyer-Moore, Game Edukasi, Android

\section{PENDAHULUAN}

Game tebak kata ialah game yang menuntut pemain buat menebak kata yang tersembunyi satu demi satu per karakternya. Pada masa terdahulu, game tebak kata dilaksanakan dengan memakai media kertas serta pensil ataupun pena buat menulis tebakan serta jawaban. Sampai dikala ini, game tebak kata masih digemari oleh warga yang kesimpulannya jadi bermacam berbagai varian semacam pencarian kata, teka teki silang, permainan ejaan, serta anagram.

Saat ini, teknologi semakin berkembang, termasuk teknologi dalam permainan atau game. Permainan atau game menjadi suatu kebutuhan hiburan bagi anak-anak hingga orang tua, salah satunya game berbasis komputer (Suprianingsih, 2019). Permainan berbasis komputer ialah sarana game yang positif dengan pendekatan cocok tahap pertumbuhan anak dalam belajar. Pendidikan dilaksanakan dalam keadaan yang menggugah serta memberi kemudahan untuk anak guna belajar lewat kegiatan yang bersifat konkrit cocok dengan perkembangan serta pertumbuhan dan kehidupan anak (Surati, 2014). Salah satu contoh game berbasis komputer adalah game dalam genre First Person Shooter yang merupakan game yang paling banyak diminati saat ini. Game dengan genre ini memungkinkan pemain menggunakan senjata dengan sudut pandang orang pertama dana hanya menampilkan senjata yang dipegang (Ramadhan, 2020).

Dalam penyelesaian game tebak kata untuk mencocokkan jawaban dengan kunci jawaban secara manual memerlukan waktu yang lebih lama dibandingkan dengan mesin. Sedangkan penyelesaian otomatis seperti halnya mesin dapat menerapkan algoritma yang dapat mempermudah pencocokan. Algoritma Booyer-Moore yang merupakan salah satu algoritma pencarian string yang nantinya diterapkan untuk mencocokkan jawaban dengan kunci jawaban. Algoritma Boyer Moore merupakan algoritma pencarian string yang dipublikasikan oleh Robert S. Boyer dan J. Strother Moore pada tahun 1977 (Kristanto dkk, 2016). Algoritma ini dapat diterapkan dalam game tebak kata yang diimplementasikan dalam wujud game berbasis komputer dengan mulai mencocokkan karakter dari sebelah kanan pattern. Ide dibalik algoritma ini merupakan kalau dengan mengawali pencocokkan karakter dari kanan, serta bukan dari kiri, hingga hendak lebih banyak data yang didapat. Game word search puzzle ialah studi yang pula memakai algoritma Boyer Moore. Penyelesaian dalam game tersebut ialah mendapatkan seluruh kata yang tersembunyi di papan game.

Berdasarkan paparan tersebut diketahui bahwa sejauh ini belum ada game Tebak Kata dengan menerapkan algoritma Boyer Moore berbasis Android. Oleh karena itu, melalui penelitian ini penulis menggagas pengembangan game Tebak Kata berbasis android dengan mengimplementasikan algoritma Boyer Moore. Game ini dibuat dalam genre First Person Shooter dengan menggunakan panah sebagai senjata. Dalam game tersebut, pemain dapat menembak sebuah papan yang berisikan huruf-huruf acak untuk mengisi kolom jawaban pada pertanyaan yang sudah tersedia. Terdapat pula beberapa rintangan seperti pergerakan acak pada papan dan waktu yang terbatas. Dengan adanya game ini, diharapkan lebih menarik minat dalam belajar dan bermain. 


\section{TINJAUAN PUSTAKA}

\subsection{Penelitian Terdahulu}

Kristanto (2016) pada penelitian dengan judul "Implementasi Algoritma Boyer-Moore pada Permainan Word Search Puzzle". Tujuan penelitian ini yaitu menciptakan suatu game untuk sarana hiburan dan melatih kecepatan berfikir, menerapkan algoritma boyer moore untuk mencari kata-kata rahasia yang ada pada game. Pengujian dilakukan dengan menekan tombol hint memilih kata secara acak di dalam bidang permainan yang tersedia kemudian sistem dapat mensimulasikan tahapan pencarian algoritma Boyer Moore untuk mencari kata yang tersembunyi dalam permainan. Hasil dari pengujian yang dilakukan pada sistem ketepatan aloritma Boyer Mooredalam mencari kata tersembunyi pada game Word Search Puzzle dengan ketepatan $100 \%$.

Argakusumah (2014) pada penelitian selanjutnya dengan judul "Implementasi Algoritma Boyer-Moore pda Aplikasi Kamus Kedokteran Berbasis Android". Tujuan penelitian ini yaitu untuk mencari efisiensi dalam proses pencarian pada kamus kedokteran. Pengujian dilakukan dengan cara responden diminta untuk melakukan pencarian kata suatu istilah pada masing-masing kategori. Hasil dari pengujian yang dilakukan pada sistem pencarian dengan algoritma Boyer Moore berhasil dilakukan dengan memberikan hasil yang sesuai yang diharapkan.

Efendi (2014) pada penelitian selanjutnya dengan judul "Rancang Bangun Aplikasi Kamus Indonesia-Minang, Minang-Indonesia Berbasis Android". Tujuan penelitian ini yaitu menciptakan kamus dan media pembelajaran tentang Bahasa Minangkabau. Persamaan dari penelitian ini adalah menerapkan algoritma boyer moore sebagai algoritma pencariannya.

Darmawan (2018) pada penelitian selanjutnya dengan judul "Implementasi Algoritma Boyer Moore Pada Aplikasi Kamus Istilah Kebidanan Berbasis Web". Tujuan penelitian ini yaitu menciptakan kamus yang mencakup istilah kebidanan seperti pernyakit, obat-obatan, istilah istilah medis yang biasa digunakan dalam praktik kebidanan. Pengujian yang dilakukan pada penelitian ini dengan melakukan pencarian kata yang berhubungan dengan ilmu kebidanan. Hasil yang dilakukan pada sistem dapat menampilkan penjelasan dari beberapa kata masukkan.

\subsection{Artificial Intelligence}

Kecerdasan buatan( artificial intelligence) ialah salah satu bagian dari ilmu computer yang menekuni gimana membuat mesin( pc) bisa melaksanakan pekerjaan semacam serta sebaik yang dicoba oleh manusia apalagi dapat lebih baik dari pada yang dicoba manusia.

Artificial intelligence merupakan buat mengenali serta memodelkan proses- proses berpikir manusia serta mendesain mesin supaya bisa menirukan sikap manusia. Cerdas, berarti mempunyai pengetahuan ditambah pengalaman. Penalaran( gimana membuat keputusan serta mengambil aksi), moral yang baik. manusia cerdas dalam menuntaskan kasus sebab manusia memiliki pengetahuan serta pengalaman. Pengetahuan diperoleh dari belajar. Terus menjadi banyak bekal pengetahuan yang dipunyai pasti lebih sanggup menuntaskan kasus. Tetapi bekal pengetahuan tidak cukup, manusia pula diberi ide buat melaksanakan penalaran, mengambil keputusan bersumber pada pengetahuan serta pengalaman yang dipunyai. Tanpa mempunyai keahlian buat menalar dengan baik, manusia dengan segudang pengalaman serta pengetahuan tidak bisa menuntaskan permasalahan dengan baik. Demikian pula dengan keahlian pengalaman yang mencukupi manusia tidak dapat menuntaskan permasalahan dengan baik (Dahria, 2008).

\subsection{Boyer-Moore}

Algoritma Boyer- Moore ialah algoritma pencarian string yang telah dikembangkan oleh Robert S. Boyer serta J. Strother Moore pada tahun 1977. Algoritma ini dinilai algoritma yang sangat efektif pada aplikasi yang bersifat universal. Tidak seperti algoritma pencarian string lain, algoritma BoyerMoore mulai mencocokkan karakter dari sebelah kanan pattern. Ide terbalik algoritma ini merupakan kalau dengan mengawali pencocokkan karakter dari kanan, bukan dari kiri, hingga hendak lebih banyak data yang didapat (Kristanto, 2016).

Adapun langkah-langkah dari algoritma BoyerMoore adalah sebagai berikut (Argakusumah, 2014).

1. Algoritma Boyer-Moore mulai mencocokkan pattern pada awal teks.

2. Mencocokkan karakter per karakter pattern dengan karakter di teks yang bersesuaian dari kanan ke kiri.

3. Jika karakter di pattern dan di teks yang dibandingkan tidak cocok (mismatch), langsung ke langkah 5.

4. Jika semua karakter di pattern cocok, kemudian algoritma akan memberitahukan penemuan di posisi ini dan selesai.

5. Algoritma akan menggeser pattern dengan memaksimalkan nilai penggeseran badcharacter, lalu mengulangi langkah 2 sampai pattern berada di ujung teks.

Contoh:

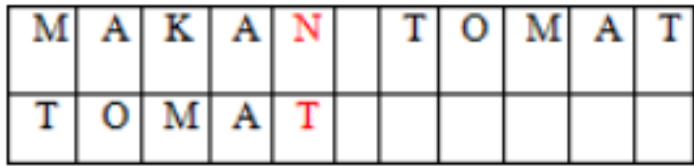

Gambar 1. contoh proses algoritma

Pada contoh gambar di atas, dengan melaksanakan perbandingan dari posisi paling akhir 
string bisa dilihat kalau karakter" n' pada string" makan" tidak sesuai dengan karakter" $t$ " pada string" tomat" yang dicari, serta karakter" n" tidak pernah terdapat dalam string " tomat" yang dicari sehingga string" tomat" bisa digeser melewati string" makan", sehingga letaknya semacam berikut.

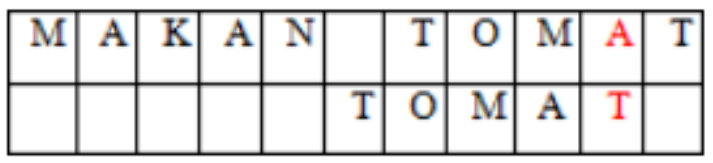

Gambar 2. contoh proses algoritma

Dalam contoh tampak kalau algoritma BoyerMoore mempunyai loncatan karakter yang besar sehingga memesatkan pencarian string sebab dengan cuma mengecek sedikit karakter, bisa langsung dikenal kalau string yang dicari tidak ditemui serta bisa digeser ke posisi selanjutnya.

\section{METODE PENELITIAN}

\subsection{Metode}

Metode yang digunakan pada penelitian ini adalah penelitian dan pengembangan (Research and Development) bertujuan untuk mengembangkan aplikasi game tebak kata menggunakan algoritma boyer moore. Metode penelitian dan pengembangan adalah metode yang digunakan untuk menghasilkan produk perangkat lunak dan menguji kelayakannya. Pada penelitian ini, peneliti membangun aplikasi game tebak kata menggunakan metode waterfall. Alasannya metode waterfall dalam pelaksanaannya dilakukan secara bertahap, sehingga kualitan dari sistem yang dihasilkan akan baik. Dalam metode waterfall ini digambarkan hubungan antara tahap pengembangan aplikasi hingga dengan tahap pengujiannya. Alur penelitian yang digunakan adalah sebagai berikut.

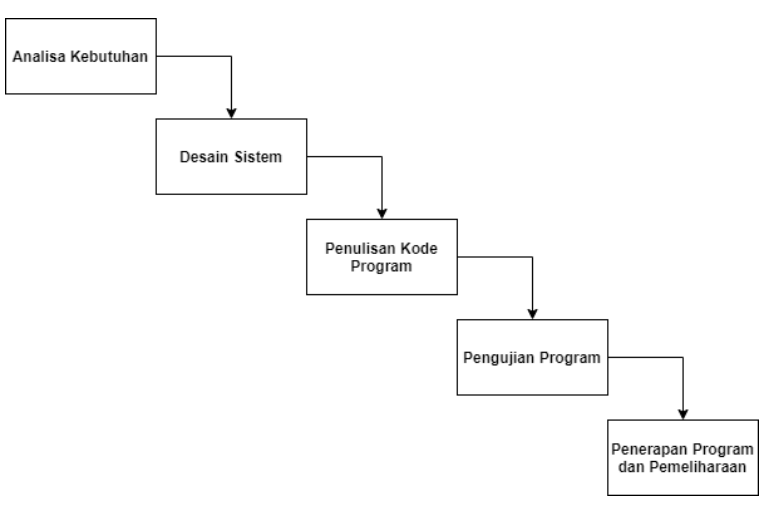

Gambar 3. Metode Model Waterfall

\subsection{Analisis Kebutuhan Fungsional}

Kebutuhan fungsional pada penelitian ini adalah sebagai berikut.

1. Game memiliki fitur nyawa.

2. Game memiliki fitur pop up jawaban benar.

3. Game mampu menampilkan huruf yang berasil di panah.

4. Game mampu melakukan restart level saat nyawa habis.

5. Game memiliki fitur pengaturan suara latar pada game.

\subsection{Analisis Kebutuhan Non Fungsional}

Kebutuhan nonfungsional pada penelitian ini adalah sebagai berikut.

1. Game ini bisa dijalankan oleh perangkat dengan OS Android.

2. Game ini mempunyai 3 level.

3. Game ini mempunyai backsound yang dapat diatur oleh pengguna.

\subsection{Flowchart Game}

Alur proses system game tebak kata saat memulai menjalankan game akan masuk pada menu awal yang menampilkan button mulai game, cara bermain, pengaturan, tentang, dan keluar. Jika player memilih memulai game, maka player akan dilanjutkan pada game dengan tingkat kesulitan level 1. Pertama game akan melakukan pengecekan timer, apakah waktunya sudah melewati 1 menit atau belum. Jika sudah melewati maka player tidak dapat menginputkan jawaban pada game dan game over. Jika masih ada waktu player dapat melakukan input jawaban. Setelah menginputkan jawaban, jawaban akan dicek apakah jawaban benar atau salah. Jika jawaban salah nyawa akan dikurangi 1 dan akan dilakukan pengecekan nyawa apakah nyawa lebih dari sama dengan 1? Jika ya player dapat memasukkan jawaban lagi, jika tidak game over. Setelah game over player akan ditawarkan apakah ingin bermain Kembali? Jika iya maka player akan di arahkan pada game lagi, dan jika tidak player akan diarahkan pada tampilan menu awal. Jika benar player dapat melanjutkan ke level 2. Begitu juga seterusnya hingga pada tingkat kesulitan level 3. Pada tampilan menu awal. Jika player memilih menu cara bermain, maka player akan diarahkan pada halaman cara bermain game tersebut. Jika player memilih pengaturan player akan diarahkan pada halaman pengaturan musik. Jika player memilih menu Tentang, maka player akan diarahkan pada halaman info developer yang mengembangkan game tersebut. jika player memilih menu keluar, maka game akan dihentikan dan keluar. Seperti pada gambar 4 berikut. 


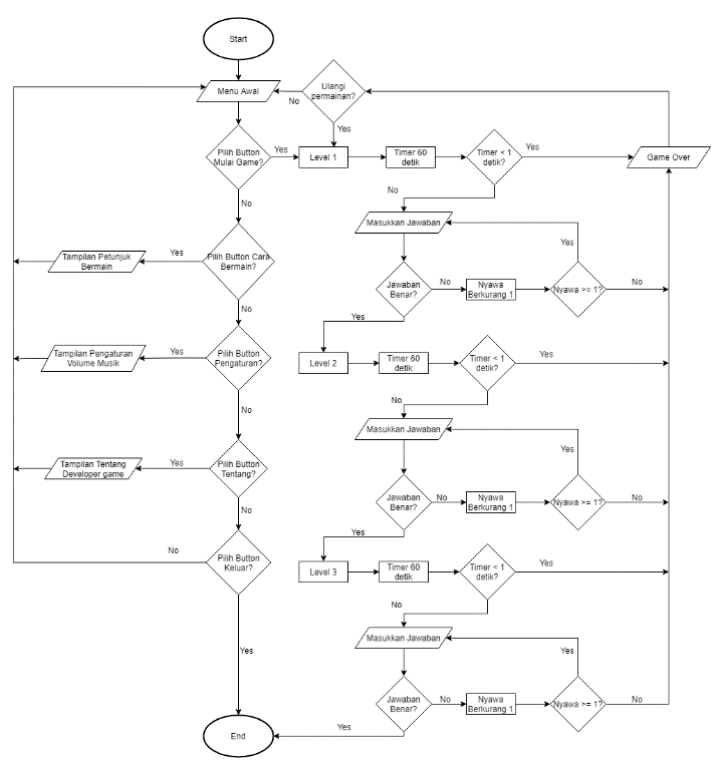

Gambar 4. Alur Proses Game

\subsection{Flowchart Boyer Moore}

Flowchart ini menggambarkan alur proses pencarian string algoritma Boyer-Moore, proses awal yang dilakukan yaitu start kemudian menginputkan pattern. Setelah itu melakukan inisialisasi nilai awal S $=0$. Cek kondisi apakah nilai variable $\mathrm{S}<=$ (Panjang text - Panjang pattern) ? jika tidak maka akan langsung end, jika iya maka akan melakukan inisialisasi nilai awal $\mathrm{J}=$ Panjang pattern -1 . Kemudian cek kondisi apakah $\mathrm{J}>=0$ \&\& pattern [J] $==$ text $[\mathrm{S}+\mathrm{J}]$ ? jika iya maka nilai variable $\mathrm{J}$ dikurangi 1 dan melakukan cek kondisi kembali apakah variable $\mathrm{J}$ masih memiliki nilai $>=0 \& \&$ pattern[J] $==$ text $[\mathrm{S}+\mathrm{J}]$, jika tidak maka program akan keluar dari perulangan kemudian nilai variable $\mathrm{J}$ akan dilanjutkan pada pengecekan kondisi berikutnya apakah $\mathbf{J}<0$ ? Jika iya maka output pattern ditemukan, jika tidak akan dilakukan proses pergeseran $\mathrm{S}+=$ math.max $(1, \mathrm{~J}$ - lo). Nilai variable $S$ akan ditambahkan dengan nilai paling besar antara 1 dengan $\mathrm{J}$ dikurangi index kemunculan karakter yang di cari. Dan nilai variable $S$ dikembalikan ke pengecekan kondisi apakah $\mathrm{S}<=$ (Panjang text - Panjang pattern)? Jika nilai S lebih kecil maka akan melanjukan proses dan pengecekannya lagi, dan jika tidak maka program akan keluar dari perulangan dan selesai. Seperti pada gambar 3.3 berikut.

\section{HASIL PEMBAHASAN}

\subsection{Implementasi Sistem}

Implementasi system merupakan suatu proses dalam menerapkan rancangan system yang telah dibuat agar dapat dijalankan dalam bentuk aplikasi. Selain itu, pada bagian pengujian akan dijelaskan hasil dari penerapan algoritma Boyer-Moore pada pengembangan game Tebak Kata. Setelah hasil uji coba dilakukan, akan ditentukan apakah rancangan ini dapat memenuhi tujuan yang akan dicapai seperti apa yang telah dijelaskan pada bagian pendahuluan.

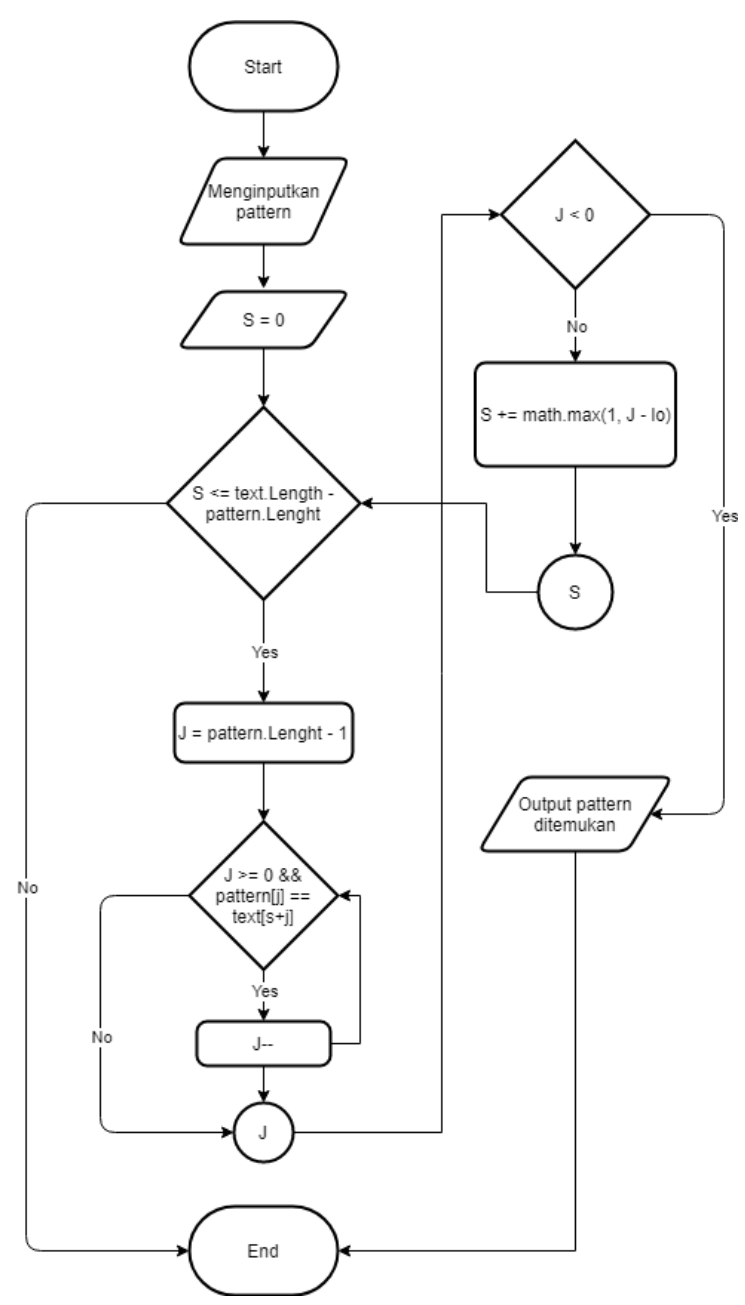

Gambar 5. Flowchart Boyer Moore

\subsection{Penjelasan Menu Game}

Pada tampilan menu utama dalam game "Tebak Kata" terdapat 5 tombol, yaitu tombol untuk memulai game, tombol "tutorial" yang berisikan penjelasan tentang game, tombol pengaturan yang berisikan pengaturan untuk volume suara music, tombol Tentang yang berisikan tentang pembuat game itu sendiri, lalu ada tombol untuk keluar dari game. Seperti yang ditunjukkan pada Gambar 6.

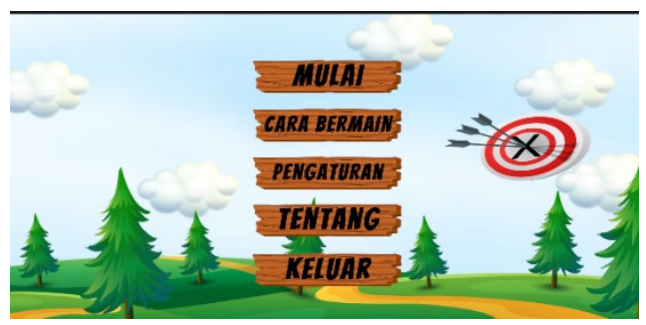

Gambar 6. Tampilan Menu Utama Game 


\subsection{Tampilan Level 1}

Pada tampilan game level 1 ini, terdapat sejumlah papan target yang berisikan huruf alfabet. Player akan diberikan kata-kata petunjuk untuk ditebak. Player harus menembakkan anak panah pada papan target untuk menebak kata rahasianya. Terdapat 3 gambar bentuk hati di pojok kanan atas. Player diberikat tiga kali kesempatan salah dalam menebak huruf. Seperti yang ditunjukkan pada Gambar ..

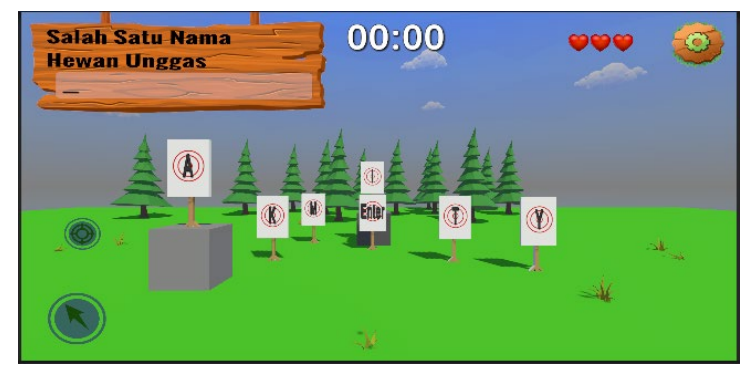

Gambar 7. Tampilan Game Level 1

\subsection{Tampilan Level 2}

Pada tampilan game level 2 ini, tingkat kesulitan akan ditingkatkan. Papan target yang berisikan huruf alfabet memiliki pergerakan ke kanan dan kesamping. Seperti yang ditunjukkan pada Gambar 8 .

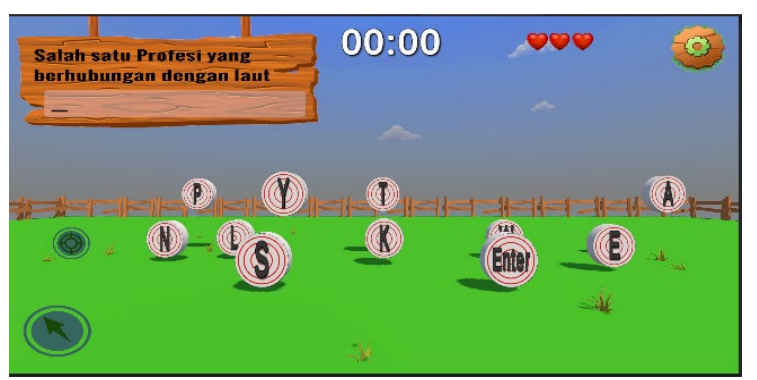

Gambar 8. Tampilan Game Level 2

\subsection{Tampilan Level 3}

Pada tampilan game level 3 ini, memiliki durasi waktu 1 menit setiap tebakan. Papan target terdapat 2 jenis, papan target diam dan bergerak ke kanan dan ke kiri. Seperti yang ditunjukkan pada Gambar 9.

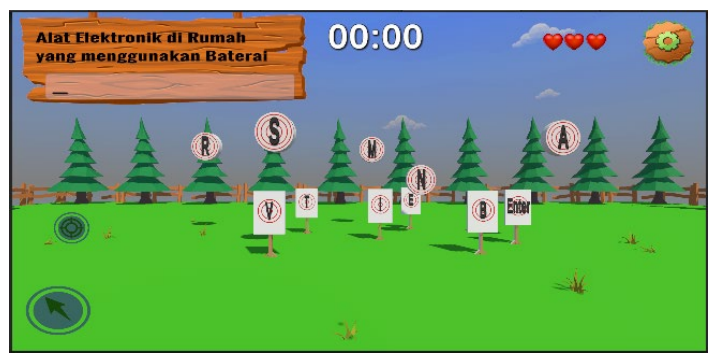

Gambar 9. Tampilan Game Level 3

\subsection{Pengujian Boyer Moore}

Pengujian algoritma akan dilakukan dengan cara mencocokkan pattern dengan text. Setelah itu akan dilihat keberhasilan pencocokan pattern yang dicari terhadap text, apabila semua karakter pada pattern cocok akan memunculkan tampilan jawaban benar. Jika karakter pada pattern tidak cocok dengan karakter pada teks, algoritma akan menggeser pattern.

Tabel 1. Pengujian Boyer Moore

\begin{tabular}{|l|l|l|l|l|l|l|l|l|l|}
\hline Posisi & 0 & 1 & 2 & 3 & 4 & 5 & 6 & 7 & 8 \\
\hline Teks & A & Y & A & M & & I & T & I & K \\
\hline Pattern & I & T & I & K & & & & & \\
\hline
\end{tabular}

Mencocokkan karakter "K" pada pattern dengan karakter "M" pada teks. Dikarenakan tidak cocok (mismatch) dan pada pattern tidak ada karakter "M" maka:

$\mathrm{i}($ new $)=\mathrm{i}+(\mathrm{J}-(-1))$

i(new) : nilai pergeseran

$\mathrm{J}$ : indeks pengecekan terakhir

$\mathrm{i}($ new $)=\mathrm{i}+(3+1)$

$i($ new $)=i+4$

$i($ new $)=4$

Sehingga diperoleh jumlah pergeseran pattern i(new) $=4$

Tabel 2. Pengujian Boyer Moore

\begin{tabular}{|l|l|l|l|l|l|l|l|l|l|}
\hline Posisi & 0 & 1 & 2 & 3 & 4 & 5 & 6 & 7 & 8 \\
\hline Teks & A & Y & A & M & & I & T & I & K \\
\hline Pattern & & & & & I & T & I & K & \\
\hline
\end{tabular}

Ketika pengecekkan karakter "K" pada pattern ternyata yang ditemui karakter "I" pada teks. Dikarenakan tidak cocok (mismatch) akan dilakukan seolah-olah karakter "I" pada pattern sejajar dengan "I" pada teks saat posisi pengecekan terakhir:

$\mathrm{i}($ new $)=\mathrm{i}+(\mathrm{J}-\mathrm{lo})$

i(new) : nilai pergeseran

$\mathrm{J}$ : indeks pengecekan terakhir lo: indeks kemunculan karakter "I"

$i($ new $)=i+(7-6)$

$i($ new $)=i+1$

$\mathrm{i}($ new $)=1$

Sehingga diperoleh jumlah pergeseran pattern i(new) $=1$

Tabel 3.Pengujian Boyer Moore

\begin{tabular}{|l|l|l|l|l|l|l|l|l|l|}
\hline Posisi & 0 & 1 & 2 & 3 & 4 & 5 & 6 & 7 & 8 \\
\hline Teks & A & Y & A & M & & I & T & I & K \\
\hline Pattern & & & & & & I & T & I & K \\
\hline
\end{tabular}

Mencocokkan karakter "K" pada pattern dengan karakter "K" pada teks. Dikarenakan dua karakter tersebut sama dan cocok maka posisi pengecekan akan diturunkan j--.

Tabel 4. Pengujian Boyer Moore

\begin{tabular}{|l|l|l|l|l|l|l|l|l|l|}
\hline Posisi & 0 & 1 & 2 & 3 & 4 & 5 & 6 & 7 & 8 \\
\hline Teks & A & Y & A & M & & I & T & I & K \\
\hline Pattern & & & & & & I & T & I & K \\
\hline
\end{tabular}


Apabila semua karakter pada pattern sama, maka algoritma Boyer Moore akan menyatakan bahwa pattern pada index ke 5 dan akan menampilkan bahwa jawabannya benar.

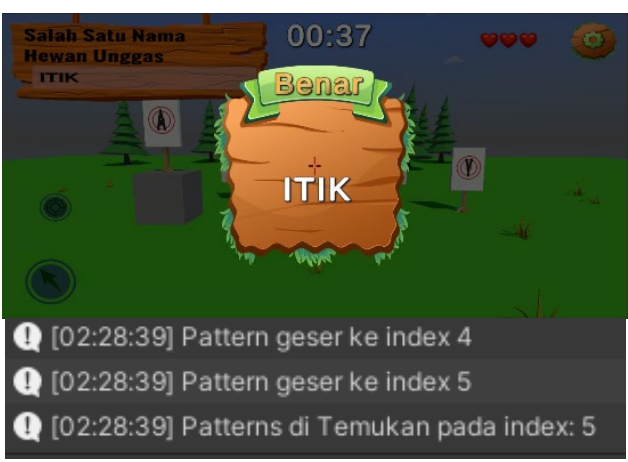

Gambar 10. Hasil Pengujian Boyer Moore

\subsection{Pengujian Black Box}

Pengujian dengan metode black box merupakan pengujian yang dilakukan untuk mengamati hasil running pada program, untuk menguji fungsionalitas pada sistem apakah berjalan dengan baik atau tidak. Hasil pengujian black box dapat dilihat pada tabel 5

Tabel 5. Pengujian Black Box

\begin{tabular}{|c|c|c|c|c|}
\hline No & Kasus/Diuji & $\begin{array}{c}\text { Hasil yang } \\
\text { Diharapkan }\end{array}$ & $\begin{array}{c}\text { Hasil } \\
\text { Pengujian } \\
\end{array}$ & Hasil \\
\hline 1. & $\begin{array}{l}\text { Menekan } \\
\text { Button } \\
\text { Mulai }\end{array}$ & $\begin{array}{l}\text { Masuk ke } \\
\text { dalam } \\
\text { permainan } \\
\text { saat menekan } \\
\text { tombol mulai }\end{array}$ & $\begin{array}{l}\text { Masuk ke } \\
\text { dalam } \\
\text { permainan }\end{array}$ & Berhasil \\
\hline 2. & $\begin{array}{l}\text { Menekan } \\
\text { Button Cara } \\
\text { Bermain }\end{array}$ & $\begin{array}{l}\text { Saat menekan } \\
\text { tombol cara } \\
\text { bermain akan } \\
\text { masuk ke } \\
\text { tampilan tata } \\
\text { cara bermain }\end{array}$ & $\begin{array}{l}\text { Masuk ke } \\
\text { dalam cara } \\
\text { bermain }\end{array}$ & Berhasil \\
\hline 3. & $\begin{array}{l}\text { Menekan } \\
\text { Button } \\
\text { Tentang }\end{array}$ & $\begin{array}{l}\text { Masuk ke } \\
\text { dalam tentang } \\
\text { developer }\end{array}$ & $\begin{array}{l}\text { Masuk ke } \\
\text { dalam tentang } \\
\text { developer }\end{array}$ & Berhasil \\
\hline 4. & $\begin{array}{l}\text { Menekan } \\
\text { Tombol } \\
\text { Keluar } \\
\end{array}$ & $\begin{array}{l}\text { Dapat keluar } \\
\text { dari aplikasi } \\
\text { permainan }\end{array}$ & $\begin{array}{l}\text { Keluar dari } \\
\text { aplikasi } \\
\text { permainan }\end{array}$ & Berhasil \\
\hline 5. & $\begin{array}{l}\text { Swipe layar } \\
\text { bagian } \\
\text { kanan }\end{array}$ & $\begin{array}{l}\text { Dapat } \\
\text { merotasi arah } \\
\text { kamera }\end{array}$ & $\begin{array}{l}\text { Kamera } \\
\text { merotasi } \\
\text { sesuai dengan } \\
\text { arah swipe } \\
\text { pada layar } \\
\text { bagian kanan }\end{array}$ & Berhasil \\
\hline 6. & $\begin{array}{l}\text { Swipe layar } \\
\text { bagian kiri } \\
\text { dan tengan }\end{array}$ & $\begin{array}{l}\text { Tidak dapat } \\
\text { merotasi arah } \\
\text { kamera }\end{array}$ & $\begin{array}{l}\text { Sudut } \\
\text { pandang tidak } \\
\text { berubah sama } \\
\text { sekali dan } \\
\text { tetap diam }\end{array}$ & Berhasil \\
\hline 7. & $\begin{array}{l}\text { Menekan } \\
\text { Button } \\
\text { Bidik }\end{array}$ & $\begin{array}{l}\text { Karakter akan } \\
\text { melakukan } \\
\text { gerakan } \\
\text { membidik }\end{array}$ & $\begin{array}{l}\text { Karakter } \\
\text { melakukan } \\
\text { gerakan } \\
\text { membidik }\end{array}$ & Berhasil \\
\hline 8. & $\begin{array}{l}\text { Menekan } \\
\text { Button } \\
\text { Tembak }\end{array}$ & $\begin{array}{l}\text { Setelah } \\
\text { menekan } \\
\text { tombol bidik } \\
\text { kemudian } \\
\text { tombol } \\
\text { tembak } \\
\text { karakter akan }\end{array}$ & $\begin{array}{l}\text { Karakter } \\
\text { melakukan } \\
\text { gerakan } \\
\text { menarik anak } \\
\text { panah saat } \\
\text { button dilepas } \\
\text { anak panah } \\
\end{array}$ & Berhasil \\
\hline
\end{tabular}

\begin{tabular}{|c|c|c|c|c|}
\hline & & $\begin{array}{l}\text { melakukan } \\
\text { gerakan } \\
\text { menarik anak } \\
\text { panah dan } \\
\text { menembakkan } \\
\text { anak panah } \\
\end{array}$ & ditembakkan & \\
\hline 9. & $\begin{array}{l}\text { Menekan } \\
\text { Button } \\
\text { Tembak } \\
\text { sebelum } \\
\text { menekan } \\
\text { Button } \\
\text { Bidik }\end{array}$ & $\begin{array}{l}\text { Karakter tidak } \\
\text { akan } \\
\text { melakukan } \\
\text { apa-apa }\end{array}$ & $\begin{array}{l}\text { Karakter tetap } \\
\text { diam pada } \\
\text { posisi awal }\end{array}$ & Berhasil \\
\hline 10 & $\begin{array}{l}\text { Menjawab } \\
\text { tebakan } \\
\text { dengan } \\
\text { benar }\end{array}$ & $\begin{array}{l}\text { Muncul } \\
\text { tampilan } \\
\text { jawaban benar }\end{array}$ & $\begin{array}{l}\text { Muncul } \\
\text { tampilan } \\
\text { jawaban benar } \\
\text { kemudian ke } \\
\text { tebakan } \\
\text { selanjutnya }\end{array}$ & Berhasil \\
\hline 11 & $\begin{array}{l}\text { Menjawab } \\
\text { tebakan } \\
\text { dengan } \\
\text { salah }\end{array}$ & $\begin{array}{l}\text { Nyawa } \\
\text { berkurang satu } \\
\text { dan muncul } \\
\text { tulisan } \\
\text { jawaban salah }\end{array}$ & $\begin{array}{l}\text { Muncul } \\
\text { tulisan } \\
\text { jaawaban } \\
\text { salah dan } \\
\text { nyawa } \\
\text { berkurang satu }\end{array}$ & Berhasil \\
\hline 12 & $\begin{array}{l}\text { Button } \\
\text { Tidak pada } \\
\text { halaman } \\
\text { kalah }\end{array}$ & $\begin{array}{l}\text { Kembali ke } \\
\text { Menu awal }\end{array}$ & $\begin{array}{l}\text { Masuk ke } \\
\text { Menu Awal }\end{array}$ & Berhasil \\
\hline 13 & $\begin{array}{l}\text { Menekan } \\
\text { Button Next } \\
\text { pada } \\
\text { halaman } \\
\text { level } \\
\text { komplit }\end{array}$ & $\begin{array}{l}\text { Masuk ke } \\
\text { level } \\
\text { berikutnya }\end{array}$ & $\begin{array}{l}\text { Berhasil } \\
\text { masuk ke } \\
\text { level } \\
\text { berikutnya }\end{array}$ & Berhasil \\
\hline 14 & $\begin{array}{l}\text { Menekan } \\
\text { Button } \\
\text { Home pada } \\
\text { halaman } \\
\text { level } \\
\text { komplit }\end{array}$ & $\begin{array}{l}\text { Kembali ke } \\
\text { Menu awal }\end{array}$ & $\begin{array}{l}\text { Masuk } \\
\text { kembali ke } \\
\text { Menu Awal }\end{array}$ & Berhasil \\
\hline 15 & $\begin{array}{l}\text { Menggeser } \\
\text { slider ke } \\
\text { arah kiri } \\
\text { pada } \\
\text { halaman } \\
\text { pengaturan }\end{array}$ & $\begin{array}{l}\text { Semakin ke } \\
\text { kiri Volume } \\
\text { musik } \\
\text { semakin } \\
\text { mengecil }\end{array}$ & $\begin{array}{l}\text { Volume musik } \\
\text { game } \\
\text { mengecil }\end{array}$ & Berhasil \\
\hline 16 & $\begin{array}{l}\text { Menggeser } \\
\text { slider ke } \\
\text { arah kanan } \\
\text { pada } \\
\text { halaman } \\
\text { pengaturan }\end{array}$ & $\begin{array}{l}\text { Semakin ke } \\
\text { kanan Volume } \\
\text { musik } \\
\text { semakin } \\
\text { membesar }\end{array}$ & $\begin{array}{l}\text { Volume musik } \\
\text { game } \\
\text { membesar }\end{array}$ & Berhasil \\
\hline
\end{tabular}

Dari hasil pengujian black box menunjukkan bahwa game tebak kata sudah berjalan sesuai dengan hasil yang diharapkan dari setiap test case-nya.

\subsection{Pengujian Perangkat Android}

Pada pengujian ini, game dijalakan pada perangkat android untuk menguji performa game "Tebak Kata". Hasil pengujian perangkat dapat dilihat pada Tabel 6.

Tabel 6. Pengujian Perangkat

\begin{tabular}{|c|c|c|c|c|c|}
\hline No & $\begin{array}{c}\text { Merk } \\
\text { Hp }\end{array}$ & RAM & OS & Resolusi & Hasil Uji \\
\hline 1. & Redmi 8 & 3 GB & 9 & $\begin{array}{c}710 \times 1520 \\
\text { pixels }\end{array}$ & $\begin{array}{c}\text { Tampilan responsive } \\
\text { dan game berjalan } \\
\text { lancar }\end{array}$ \\
\hline 2. & Samsung & 4 GB & 9 & $2340 \times$ & Tampilan agak pipih \\
\hline
\end{tabular}




\begin{tabular}{|c|c|c|c|c|c|}
\hline & A50 & & & 1080 pixels & $\begin{array}{c}\text { dan game berjalan } \\
\text { lancar }\end{array}$ \\
\hline 3. & $\begin{array}{c}\text { Asus } \\
\text { Zenfone } \\
3\end{array}$ & $3 \mathrm{~GB}$ & 7 & $\begin{array}{c}720 \times 1280 \\
\text { pixels }\end{array}$ & $\begin{array}{c}\text { Tampilan responsive } \\
\text { dan game berjalan } \\
\text { dengan lancar }\end{array}$ \\
\hline 4. & Oppo F9 & $4 \mathrm{~GB}$ & 8 & $\begin{array}{c}2340 x \\
1080 \text { pixels }\end{array}$ & $\begin{array}{c}\text { Tampilan responsive } \\
\text { dan game berjalan } \\
\text { dengan lancar }\end{array}$ \\
\hline 5. & $\begin{array}{c}\text { Asus } \\
\text { Zenfone } \\
4\end{array}$ & $4 \mathrm{~GB}$ & 7 & $\begin{array}{c}1080 \mathrm{x} \\
1920 \\
\text { pixels }\end{array}$ & $\begin{array}{c}\text { Tampilan responsive } \\
\text { dan game berjalan } \\
\text { dengan lancar }\end{array}$ \\
\hline 6. & $\begin{array}{c}\text { Realme } \\
3\end{array}$ & $3 \mathrm{~GB}$ & 9 & $\begin{array}{c}1080 x \\
2400 \text { pixels }\end{array}$ & $\begin{array}{c}\text { Tampilan responsive } \\
\text { dan game berjalan } \\
\text { dengan lancar }\end{array}$ \\
\hline 7. & $\begin{array}{l}\text { Redmi } \\
\text { Note } 4\end{array}$ & $4 \mathrm{~GB}$ & 6 & $\begin{array}{c}1080 \mathrm{x} \\
1920 \\
\text { pixels } \\
\end{array}$ & $\begin{array}{c}\text { Tampilan responsive } \\
\text { dan game berjalan } \\
\text { dengan lancar }\end{array}$ \\
\hline 8. & $\begin{array}{l}\text { Vivo } \\
\text { Y83 }\end{array}$ & $3 \mathrm{~GB}$ & 8 & $\begin{array}{c}1080 \mathrm{x} \\
2280 \text { pixels }\end{array}$ & $\begin{array}{c}\text { Tampilan responsive } \\
\text { dan game berjalan } \\
\text { dengan lancar }\end{array}$ \\
\hline 9. & $\begin{array}{l}\text { Realme } \\
5\end{array}$ & $3 \mathrm{~GB}$ & 9 & $\begin{array}{c}1080 x \\
2340 \text { pixels }\end{array}$ & $\begin{array}{c}\text { Tampilan responsive } \\
\text { dan game berjalan } \\
\text { dengan lancar }\end{array}$ \\
\hline 10. & $\begin{array}{l}\text { Xiaomi } \\
\text { Redmi } \\
\text { Note } 5\end{array}$ & $3 \mathrm{~GB}$ & 8 & $\begin{array}{c}1080 x \\
2160 \text { pixels }\end{array}$ & $\begin{array}{c}\text { Tampilan responsive } \\
\text { dan game berjalan } \\
\text { dengan lancar }\end{array}$ \\
\hline
\end{tabular}

\subsection{Pengujian User}

Pada pengujian ini, game Tebak Kata dimainkan oleh 10 pengguna yang dapat menjalankan game Tebak Kata menggunakan salah satu perangakat android pada table 6. Hasil pengujian user dapat dilihat pada table 7 .

Tabel 7. Pengujian User

\begin{tabular}{|c|c|c|c|c|}
\hline \multirow[b]{2}{*}{ No } & \multirow[b]{2}{*}{ Pernyataan } & \multicolumn{3}{|c|}{ Opsi Penilaian } \\
\hline & & $\begin{array}{l}\text { Sangat } \\
\text { Setuju }\end{array}$ & Setuju & $\begin{array}{r}\text { Tidak } \\
\text { Setuju }\end{array}$ \\
\hline 1. & $\begin{array}{l}\text { Game yang dihasilkan } \\
\text { sangat menarik untuk } \\
\text { dimainkan }\end{array}$ & $30 \%$ & $70 \%$ & 0 \\
\hline 2. & $\begin{array}{l}\text { Kontrol game sangat mudah } \\
\text { digunakan }\end{array}$ & 0 & $100 \%$ & 0 \\
\hline 3. & $\begin{array}{l}\text { Desain game sangat menarik } \\
\text { bagi pemain }\end{array}$ & 0 & $80 \%$ & $20 \%$ \\
\hline 4. & $\begin{array}{l}\text { Tombol pada game } \\
\text { berfungsi dengan sangat } \\
\text { baik }\end{array}$ & 0 & $100 \%$ & 0 \\
\hline 5. & $\begin{array}{l}\text { Game yang dihasilkan } \\
\text { sangat memberikan nilai } \\
\text { tambah dalam kehidupan } \\
\text { sehari-hari }\end{array}$ & $20 \%$ & $80 \%$ & 0 \\
\hline 6. & $\begin{array}{l}\text { Anak panah berjalan dengan } \\
\text { benar }\end{array}$ & 0 & $100 \%$ & 0 \\
\hline 7. & \begin{tabular}{|l|} 
Game yang dihasilkan \\
sangat memberikan \\
pengalaman dalam bermain \\
menjadi lebih baik
\end{tabular} & 0 & $100 \%$ & 0 \\
\hline 8. & $\begin{array}{l}\text { Sistem menang/ } \\
\text { kalah berjalan dengan baik }\end{array}$ & 0 & $100 \%$ & 0 \\
\hline 9. & $\begin{array}{l}\text { Tingkat kesulitan pada } \\
\text { setiap level dapat } \\
\text { membuat anda semakin } \\
\text { tertantang untuk } \\
\text { memainkan game }\end{array}$ & 0 & $100 \%$ & 0 \\
\hline 10. & $\begin{array}{l}\text { Tampilan game responsif } \\
\text { dan game pada perangkat } \\
\text { berjalan dengan lancar }\end{array}$ & $50 \%$ & $40 \%$ & $10 \%$ \\
\hline
\end{tabular}

Berdasarkan tabel 7 dari 10 orang yang memainkan game tebak kata menunjukkan bahwa $30 \%$ memilih sangat setuju, 70\% memilih setuju, dan $0 \%$ memilih tidak setuju bahwa game yang dihasilkan menarik untuk dimainkan.

\section{KESIMPULAN DAN SARAN}

\subsection{Kesimpulan}

Berdasarkan langkah-langkah pengembangan yang telah dilakukan, diketahui pengembangan First Person Shooter pada game Tebak Kata berhasil dikembangkan. Adapun Kesimpulan yang dapat penulis paparkan setelah pembuatan game Tebak Kata sebagai berikut.

1. Kecerdasan buatan menggunakan algoritma Boyer-Moore berfungsi dengan baik dalam game Tebak Kata.

2. Semua tombol kontrol pemain dan tombol menu berfungsi dengan baik dan sesuai dengan yang diharapkan.

3. Pada pengujian fungsionalitas dapat berjalan secara lancar sesuai fungsinya.

4. Dari hasil pengujian kepada responden, semua kontrol dalam game dapat berjalan cukup baik.

\subsection{Saran}

Setelah dilakukan pengujian terhadap game Tebak Kata terdapat beberapa saran dari penulis untuk pengembangan game berikutnya yaitu.

1. Penyusunan tebakan pada game dapat diakses secara acak.

2. Diharapkan game berikutnya dapat memberikan desain tampilan yang lebih menarik lagi untuk pemain.

3. Menambahkan animasi cutscene pada tiap perpindahan level agar lebih menarik.

4. Menambahkan variasi tantangan yang lebih banyak agar interaksi antara game dengan pemain lebih menarik.

\section{DAFTAR PUSTAKA}

[1] Argakusumah, Kencana Wulan, and Seng Hansun. "Implementasi algoritma boyer-moore pada aplikasi kamus kedokteran berbasis android." Ultimatics: Jurnal Teknik Informatika 6.2 (2014).

[2] Dahria, M., 2008. Kecerdasan Buatan Jurnal SAINTIKOM, p.185.

[3] Darmawan, Rizky Ivan, Anif Hanifa Setianingrum, and Arini Arini. "implementasi algoritma Boyer Moore pada aplikasi kamus istilah kebidanan berbasis web." Query: Journal of Information Systems 2.1 (2018).

[4] Efendi, Rusdi, Meilia Fitri, and Desi Andreswari. "Rancang Bangun Aplikasi Kamus Bahasa Indonesia-Minang, Minang-Indonesia Berbasis Android." TEKNOSIA 1.14 (2014).

[5] J. Von Neumann and O. Morgenstern, Theory of Games and Economic Behavior (3d ed. 1953). 
[6] Kristanto, Steven, and R. Gunawan Santosa. "Implementasi Algoritma Boyer-Moore pada Permainan Word Search Puzzle." Proceedings of KNASTIK (2016).

[7] Ramadhan, Ibnu, and Agung Purwanto. "Pengembangan Teknoloogi Game Indonesia untuk Permainan First Person Shooter (FPS) 3D Multiplayer "Code to Shoot" Menggunakan Unity Network (UNET) Berbasis Mobile." Jurnal Teknologi Informasi Universitas Lambung Mangkurat (JTIULM) 5.2 (2020).

[8] Suprianingsih, Suprianingsih, Susa Rita Loravianti, and Syafwandi Syafwandi.
"Perancangan Game Sebagai Media Pembelajran Berkebun Hidroponik." PROPORSI: Jurnal Desain, Multimedia dan Industri Kreatif 2.1 (2019): 90-104.

[9] Surati, S. "Strategi pembangunan game edukasi berbasis desktop untuk anak usia 4-6 tahun." Journal Speed-Sentra Penelitian Edukasi Dan Engineering 6.1 (2014).

[10] Wijaya, Daniel Eka, Karina Auliasari, and Hani Zulfia Zahro. "Kombinasi Metode Finite State Machine dan Game-Based Learning pada Game Escape Form COV-Madness." JATI (Jurnal Mahasiswa Teknik Informatika) 5.1 (2021). 